\title{
Correlation between Homeostatic Model Assessment-estimated Insulin Resistance (HOMA-IR) with Asymmetric Dimethylarginine (ADMA) in Prehypertension
}

\author{
Maria Evi Novianti ${ }^{1,2}$, Syakib Bakri², Mansyur Arief ${ }^{2}$, Ferry Sandra ${ }^{1,3, *}$ \\ ${ }^{1}$ Prodia Clinical Laboratory, Jl. Kramat Raya No.150, Jakarta, Indonesia \\ ${ }^{2}$ Postgraduate Program in Clinical Biochemistry, Hasanuddin University, Jl. Perintis Kemerdekaan Km.10, Makassar, Indonesia \\ ${ }^{3}$ Department of Biochemistry and Molecular Biology, Faculty of Dentistry, Trisakti University, Jl. Kyai Tapa No.260, Jakarta, Indonesia \\ *Corresponding author. E-mail: ferrysandra@gmail.com
}

\section{Abstract}

B

ACKGROUND: Not only hypertension, prehypertension has been reported to be linked with increased cardiovascular morbidity and mortality risks as well. Prehypertension has three-fold hypertension and two-fold cardiovascular risks. Pathomechanism that links hypertension with cardiovascular is related with endothelial dysfunction and insulin resistance. Endothelial dysfunction occurs when nitric oxide (NO) biological function was impaired, whereas shown by asymmetric dimethylarginine (ADMA). Subjects with prehypertension had higher insulin resistance events than normotension, whereas shown by homeostatic model assessment-estimated insulin resistance (HOMA-IR). This research was conducted to investigate the correlation of HOMA-IR with ADMA in prehyper- and normo-tension.

METHODS: A cross-sectional comparative research was designed. Subjects were recruited and divided into prehyper- and normo-tensive groups. ADMA was measured using ELISA method, while HOMA-IR was calculated by the ratio of fasting insulin and glucose. Spearman 1-tail and Mann Whitney statistical analyses were performed.

RESULTS: Comparing to normotensive group, elevated levels of HOMA-IR and ADMA in prehypertensive group were shown, but not significant. In prehypertensive group, we found significant correlation between HOMA-IR and ADMA.

CONCLUSION: Insulin resistance and endothelial dysfunction was elevated in prehyper-compared to normotension.

Abstrak

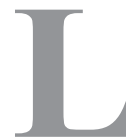

ATAR BELAKANG: Selain hipertensi, prehipertensi juga telah dilaporkan berkaitan dengan peningkatan resiko morbiditas dan mortalitas yang berkaitan dengan kardiovaskuler. Prehipertensi memiliki resiko tiga kali lipat mengalami hipertensi dan dua kali lipat mengalami kardiovaskular. Patomekanisme yang menghubungkan hipertensi dengan kardiovaskular berhubungan dengan disfungsi endotel dan resistensi insulin. Disfungsi endotel terjadi apabila fungsi biologis NO terganggu, dan parameter yang menggambarkan kondisi tersebut adalah asymmetric dimethylarginine (ADMA). Subyek dengan prehipertensi lebih resistensi insulin dibandingkan normotensi, dan parameter yang menggambarkan kondisi tersebut adalah homeostatic model assessment-estimated insulin resistance (HOMA-IR). Penelitian ini dilakukan untuk mengetahui korelasi ADMA dengan HOMA-IR pada prehiper- dan normo-tensi.

METODE: Dilakukan penelitian komparasi dengan rancangan potong lintang. Subyek direkrut dan dibagi menjadi grup hiper- dan normo-tensif. ADMA diukur dengan menggunakan metode ELISA, dan HOMA-IR dihitung dengan menggunakan rasio insulin dan gula puasa. Kemudian analisa statistik Spearman 1-tail and Mann Whitney dilakukan.

HASIL: Hasil penelitian menunjukkan terdapat peningkatan kadar HOMA-IR dan ADMA pada kelompok prehipertensi dibandingkan normotensi, namun tidak bermakna. Pada kelompok prehipertensi terdapat hubungan yang bermakna antara HOMA-IR dengan ADMA. 
KEYWORDS: prehypertension, insulin resistance, endothelial dysfunction, HOMA-IR, ADMA

Indones Biomed J. 2013; 5(3): 169-72
KESIMPULAN: Terjadi peningkatan resistensi insulin dan disfungsi endotel pada prehiper- dibandingkan normo-tensi.

KATA KUNCI: prehipertensi, resistensi insulin, disfungsi endotel, HOMA-IR, ADMA

\section{Introduction}

Hypertension is an important public health issue, not only because of high prevalence, but also the cause of morbidity and mortality. In the world, the prevalence reached 1 billion, and hypertension-related death reached 7.1 million per year (1), due to increasing cardiovascular risk. (2) Hypertension and cardiovascular disease pathomechanism is related with interrelated and interacted endothelial dysfunction and insulin resistance, generating the complex mechanisms. (3) Endothelial dysfunction occurs when nitric oxide (NO) biological function was impaired, whereas asymmetric dimethylarginine (ADMA) is one of the parameters to assess the incidence of endothelial dysfunction.(4) ADMA, an L-arginine analogue, is a natural product of metabolism. ADMA will inhibit synthesis of NO, leading to endothelial dysfunction.(5) Hypertension has been reported to have relation with increase in insulin resistance, in which vascular inflammation is the core of their relationships. (6-8) Pathomechanism linking hypertension with insulin resistance is not fully understood. Insulin was suggested to stimulate sympathetic nervous system, increase kidney sodium retention, modulate cation and induce vascular smooth muscle hypertrophy.(9)

Insulin has several functions, the most important one is the regulation of glucose, and others such as vasodilatation, anti-apoptosis, anti-inflammation and anti-oxidation as defense mechanism for cardiovascular.(10) Insulin resistance is a condition in which cells become resistant to the effects of insulin, resulting normal response to insulin is reduced. Therefore higher levels of insulin are needed for optimal insulin function.

According to the Joint National Committee, prehypertension was designated whereas systolic blood pressure (SBP) 120-139 mm Hg or diastolic blood pressure (DBP) 80-89 mmHg.(1) Subject with prehypertension had incidence increase of cardiovascular disease. Moreover, compared with normo-, the prehyper-tensive group had three-fold risk of hypertension and two-fold risk of cardiovascular.(11)

Role of endothelial dysfunction and insulin resistance in elevating blood pressure was proven experimentally and clinically, however the mechanisms and dynamics of endothelial dysfunction and insulin resistance have not been elucidated. It was reported that prehypertension was correlated with insulin resistance in Japanese, Indian and American, but not in African American.(9)

In our current interest, we conducted a study to investigate the correlation of homeostatic model assessmentestimated insulin resistance (HOMA-IR) with ADMA in prehyper- and normo-tension. As insulin resistance marker, both HOMA-IR and euglycaemic clamp method were correlated with insulin resistance.(12) Meanwhile ADMA was used as endothelial dysfunction marker, since ADMA inhibit NO synthesis and endothelial function, leading to incidence of atherosclerosis. ADMA levels were increased in subjects with hypertension, hypercholesterolemia, chronic heart failure, diabetes mellitus and chronic kidney disease.(13)

\section{Methods}

A cross-sectional study was designed. Subjects were recruited and selected based on blood pressure measurement (SBP \& DBP) according to the Joint National Committee (1). Briefly, subjects with liver or kidney diseases, acute infections, anti-inflammatory or anti-oxidant drugs intake for 3 months, pregnant, were all excluded. Subjects were measured/tested for waist circumference (WC), SBP and DBP, which later divided into 2 groups: prehyper- and normo-tensive groups. All subjects were further tested for fasting plasma glucose (FPG), triglyceride, high density lipoprotein (HDL), low density lipoprotein (LDL), insulin, and ADMA.

\section{Blood Collection and Biochemical Analyses}

Blood were collected intravenously from all subjects. Serum was generated, stored and tested for all parameters. FPG, triglyceride, HDL and LDL were tested based on method routinely applied in clinical laboratory. For insulin test, we used 1 ReadyPack (Cat. No.: 02230141, Siemens Healthcare Diagnostics Inc., Tarrytown, NY). Briefly, 1 ReadyPack, named as The ADVIA Centaur Insulin assay, is a two-site sandwich immunoassay using direct chemiluminescent technology, which uses constant amounts of two antibodies. 
The first antibody is a monoclonal mouse anti-insulin antibody labeled with acridinium ester. The second antibody is a monoclonal mouse anti-insulin antibody, which is covalently coupled to paramagnetic particles. Later on, HOMA-IR was calculated using formula: fasting insulin $\mathrm{x}$ fasting glucose / 22.5. To analyze ADMA, We used Enzyme Immunoassay for the Quantitative Determination of Endogenous Asymmetric Dimethylarginine (ADMA) in Serum or Plasma (Cat. No.: 17-EA201/96, DLD Gesellschaft für Diagnostika und medizinische $\mathrm{GmbH}$, Hamburg, German). The substrate reaction was monitored at $450 \mathrm{~nm}$.

\section{Statistical Analysis}

Statistical analyses were performed using SPSS for Windows version 15.0 (USA, SPSS Inc.). To measure the difference significance of each parameter between prehyperand normo-tensive groups, we used Mann Whitney analysis. Meanwhile, to measure the correlation significance of HOMA-IR with ADMA in each group, we used Spearman 1-tail analysis.

\section{Results}

Sixty-two subjects consisting of 43 prehyper- and 19 normotensive subjects, were selected according to inclusion and exclusion criteria. The study was approved by the Ethics committee of the University of Hasanuddin (UH09060072). All subject characteristics including WC, age, DBP, SBP, FPG, triglyceride, HDL and LDL, were obtained (Table 1). HOMA-IR and ADMA results were also obtained (Table 1).

Table 1. Subject characteristics, HOMA-IR and ADMA analyses in prehyper- and normo-tensive and groups.

\begin{tabular}{lccc}
\hline \multicolumn{1}{c}{ Test } & Normotension $(\mathbf{n}=19)$ & Prehypertension $(\mathbf{n = 4 3})$ & $\boldsymbol{p}$ value \\
& Average \pm SD & Average \pm SD & \\
\hline WC $(\mathrm{cm})$ & $86.4 \pm 9.0$ & $90.3 \pm 9.7$ & 0.132 \\
Age (years) & $40.4 \pm 7.4$ & $43.9 \pm 9.0$ & 0.126 \\
DBP (mmhg) & $71.3 \pm 6.5$ & $80.6 \pm 4.5$ & $0.000^{*}$ \\
SBP (mmhg) & $107.8 \pm 7.1$ & $124.9 \pm 5.8$ & $0.000^{*}$ \\
FPG $(\mathrm{mg} / \mathrm{dL})$ & $86.8 \pm 8.2$ & $93.2 \pm 8.8$ & $0.015^{*}$ \\
Triglyceride $(\mathrm{mg} / \mathrm{dL})$ & $96.7 \pm 39.6$ & $136.4 \pm 91.1$ & $0.011^{*}$ \\
HDL $(\mathrm{mg} / \mathrm{dL})$ & $48.0 \pm 7.1$ & $47.8 \pm 9.2$ & 0.536 \\
LDL $(\mathrm{mg} / \mathrm{dL})$ & $132.7 \pm 28.8$ & $137.9 \pm 25.2$ & 0.321 \\
Insulin $(\mathrm{ulU} / \mathrm{mL})$ & $7.2 \pm 4.5$ & $8.4 \pm 6.1$ & 0.703 \\
\hline HOMA-IR & $1.547 \pm 1.022$ & $1.930 \pm 1.415$ & 0.449 \\
ADMA $(\mu \mathrm{mol} / \mathrm{mL})$ & $0.656 \pm 0.075$ & $0.678 \pm 0.151$ & 0.454 \\
\hline
\end{tabular}

* Mann Whitney test; Significant $\mathrm{p}$ value $<0.05$; SD: Standard Deviation
We found that DBP, SBP, FPG, triglyceride of prehyper- and normo-tension and were significantly different. HOMA-IR and ADMA of prehypertension were higher the ones of normotension, but not significant.

Based on Spearman 1-tail correlation analysis, we found HOMA-IR was negatively correlated with ADMA $(r=-0.171$, $\mathrm{p}=0.271)$ in normotensive group. Meanwhile HOMA-IR was significantly correlated with ADMA $(r=0.330, p=0.018)$ in prehypertensive group.

\section{Discussion}

In our current results, HOMA-IR and ADMA of prehypertensive group were higher than the ones of normotensive group. This might be related to the fact that hypertension is interrelated and interacted with endothelial dysfunction and insulin resistance.(3) ADMA is an endogenous inhibitor of endothelial NO synthesis (eNOS), was used as endothelial dysfunction parameter for this study. ADMA is synthesized from arginine residues and metabolized by dimethylarginine-dimethylaminohydrolase (DDAH) to citrulline. Increased concentration of ADMA was reported to have an association with endothelial dysfunction.(14) Meanwhile, HOMA-IR values was used as insulin resistance parameter for this study. Insulin has vasodilatory function through Phosphatidylinositol 3 Kinase (PI3K) pathway whereby insulin increases eNOS, which will then produce NO. In insulin resistance condition, the insulin does not function optimally, causing lower NO production. Meanwhile ADMA acts as an inhibitor of eNOS activity, which can also lower down production of NO. These two mechanisms in turn will cause increased vasoconstriction.

It was reported previously that endothelial dysfunction and insulin resistance were correlated in elevating blood pressure.(9) Many cross-sectional studies have examined the relationship between insulin resistance/ sensitivity and endothelial function.(15-29) In these studies, endothelial function was evaluated by high resolution brachial artery ultrasound, venous occlusion plethysmography, and laser doppler imaging techniques. Insulin sensitivity was assessed by euglycemic hyperinsulinemic clamps and HOMA-IR.(15-29) These studies suggest that insulin resistance may only partly explain the impaired endothelial function. It is also possible that other manifestations of insulin resistance such as hyperglycemia, dyslipidemia, inflammation, and obesity may be intermediary 
mediators that act in concert with insulin resistance to mediate endothelial dysfunction.(15) Therefore, although we found HOMA-IR and ADMA of prehypertensive group were higher than the ones of normotensive group, we suggest that further study should be pursued in order to correlate other factors that might playing role in endothelial dysfunction and insulin resistance in prehyper- and normotensive subjects.

\section{Conclusion}

In the prehypertension group had an increase in endothelial dysfunction which is a risk for cardiovascular disease events in which the mechanisms of endothelial dysfunction in the prehypertension group affected by insulin resistance.

\section{Acknowledgement}

This study was supported by the Prodia Education and Research Institute.

\section{References}

1. Chobanian AV, Bakris GL, Black HR, Cushman WC, Green LA, Izzo JL Jr, et al. The Seventh Report of the Joint National Committee on Prevention, Detection, Evaluation, and Treatment of High Blood Pressure: the JNC 7 report. JAMA. 2003; 289: 2560-72.

2. Dzau, V. The cardiovascular continuum and renin-angiotensinaldosterone system blockade. J Hypertens Suppl. 2005; 23: S9-17.

3. Geisler T, Bhatt DL. The role of inflammation in atherothrombosis: current and future strategies of medical treatment. Med Sci Monit. 2004; 10: RA308-16.

4. Raitakari OT, Celermajer DS. Testing for endothelial dysfunction. Ann Med. 2000; 32: 293-304.

5. Sibal L, Agarwal SC, Home PD, Boger RH. The Role of Asymmetric Dimethylarginine (ADMA) in Endothelial Dysfunction and Cardiovascular Disease. Curr Cardiol Rev. 2010; 6: 82-90.

6. Perticone F, Maio R, Sciacqua A, Andreozzi F, Iemma G, Perticone M, et al. Endothelial dysfunction and C-reactive protein are risk factors for diabetes in essential hypertension. Diabetes. 2008; 57: 167-71.

7. Furuhashi M, Ura N, Higashiura K, Murakami H, Tanaka M, Moniwa $\mathrm{N}$, et al. Blockade of the renin-angiotensin system increases adiponectin concentrations in patients with essential hypertension. Hypertension. 2003; 42: 76-81.

8. Kawamoto R, Kohara K, Tabara Y, Abe M, Kusunoki T, Miki T. Insulin resistance and prevalence of prehypertension and hypertension among community-dwelling persons. J Atheroscler Thromb. 2010; 17: $148-55$.

9. Saad MF, Rewers M, Selby J, Howard G, Jinagouda S, Fahmi S, et al. Insulin resistance and hypertension: the Insulin Resistance Atherosclerosis study. Hypertension. 2004; 43: 1324-31.

10. Yu Q, Gao F, Ma XL. Insulin says NO to cardiovascular disease. Cardiovasc Res. 2011; 15; 89: 516-24

11. Gupta P, Nagaraju SP, Gupta A, Chikkalingaiah KB. Prehypertension time to act. Saudi J Kidney Dis Transpl. 2012; 23: 223-33.
12. Matthews DR, Hosker JP, Rudenski AS, Naylor BA, Treacher DF, Turner RC. Homeostasis model assessment : insulin resistance and $\beta$-cell function from fasting plasma glucose and insulin concentrations in man. Diabetologia. 1985; 28: 412-9.

13. Sibal L, Agarwal SC, Home PD, Boger RH. The Role of Asymmetric Dimethylarginine (ADMA) in Endothelial Dysfunction and Cardiovascular Disease. Curr Cardiol Rev. 2010; 6: 82-90.

14. Oğuz A, Uzunlulu M, Yorulmaz E, Yalçin Y, Hekim N, Fici F. Effect of nebivolol and metoprolol treatments on serum asymmetric dimethylarginine levels in hypertensivepatients with type 2 diabetes mellitus. Anadolu Kardiyol Derg. 2007; 7: 383-7.

15. Muniyappa R, Sowers JR. Role of insulin resistance in endothelial dysfunction. Rev Endocr Metab Disord. 2013; 14: 5-12.

16. Steinberg HO, Chaker H, Leaming R, Johnson A, Brechtel G, Baron $\mathrm{AD}$. Obesity/insulin resistance is associated with endothelial dysfunction. Implications for the syndrome of insulin resistance. J Clin Invest. 1996; 97: 2601-10.

17. Balletshofer BM, Rittig K, Enderle MD, Volk A, Maerker E, Jacob S, et al. Endothelial dysfunction is detectable in young normotensive first-degree relatives of subjects with type 2 diabetes in association with insulin resistance. Circulation. 2000; 101: 1780-4.

18. Han KA, Patel Y, Lteif AA, Chisholm R, Mather KJ. Contributions of dysglycaemia, obesity, and insulin resistance to impaired endothelium-dependent vasodilation in humans. Diabetes Metab Res Rev. 2011; 27: 354-61.

19. Caballero AE, Arora S, Saouaf R, Lim SC, Smakowski P, Park JY, et al. Microvascular and macrovascular reactivity is reduced in subjects at risk for type 2 diabetes. Diabetes. 1999; 48: 1856-62.

20. Lteif AA, Han K, Mather KJ. Obesity, insulin resistance, and the metabolic syndrome: determinants of endothelial dysfunction in whites and blacks. Circulation. 2005; 112: 32-8.

21. Title LM, Lonn E, Charbonneau F, Fung M, Mather KJ, Verma S, et al. Relationship between brachial artery flow-mediated dilatation, hyperemic shear stress, and the metabolic syndrome. Vasc Med. 2008; $13: 263-70$

22. Lind L. Endothelium-dependent vasodilation, insulin resistance and the metabolic syndrome in an elderly cohort: the Prospective Investigation of the Vasculature in Uppsala Seniors (PIVUS) study. Atherosclerosis. 2008; 196: 795-802.

23. Wendelhag I, Fagerberg B, Hulthe J, Bokemark L, Wikstrand J. Endothelium-dependent flow-mediated vasodilatation, insulin resistance and the metabolic syndrome in 60-year-old men. J Intern Med. 2002; 252: 305-13.

24. Petrie JR, Ueda S, Webb DJ, Elliott HL, Connell JM. Endothelial nitric oxide production and insulin sensitivity. A physiological link with implications for pathogenesis of cardiovascular disease. Circulation. 1996; 93:1331-3.

25. Tack CJ, Ong MK, Lutterman JA, Smits P. Insulin-induced vasodilatation and endothelial function in obesity/insulin resistance. Effects of troglitazone. Diabetologia. 1998; 41: 569-76.

26. Hogikyan RV, Galecki AT, Pitt B, Halter JB, Greene DA, Supiano MA. Specific impairment of endothelium-dependent vasodilation in subjects with type 2 diabetes independent of obesity. J Clin Endocrinol Metab. 1998; 83: 1946-52.

27. Jaap AJ, Shore AC, Tooke JE. Relationship of insulin resistance to microvascular dysfunction in subjects with fasting hyperglycaemia. Diabetologia. 1997; 40: 238-43.

28. Watts GF, O'Brien SF, Silvester W, Millar JA. Impaired endotheliumdependent and independent dilatation of forearm resistance arteries in men with diet-treated non-insulin-dependent diabetes: role of dyslipidaemia. Clin Sci (Lond). 1996; 91: 567-73.

29. Williams SB, Cusco JA, Roddy MA, Johnstone MT, Creager MA. Impaired nitric oxide-mediated vasodilation in patients with noninsulin-dependent diabetes mellitus. J Am Coll Cardiol. 1996; 27: $567-74$. 